\title{
Pseudecheneis maurus, a new species of glyptosternine catfish (Teleostei: Sisoridae) from Central Vietnam
}

\author{
HEOK HEE $\mathrm{NG}^{1} \&$ HEOK HUI TAN ${ }^{2}$ \\ ${ }^{\prime}$ Fish Division, Museum of Zoology, University of Michigan, 1109 Geddes Avenue, Ann Arbor, Michigan 48109-1079, USA. \\ E-mail: heokheen@umich.edu \\ Current address: Raffles Museum of Biodiversity Research, Department of Biological Sciences, National University of Singapore, 6 \\ Science Drive 2, Singapore 117600. \\ ${ }^{2}$ Raffles Museum of Biodiversity Research, Department of Biological Sciences, National University of Singapore, 6 Science Drive 2, \\ Singapore 117600.E-mail:dbsthh@nus.edu.sg
}

\begin{abstract}
A new species of sisorid catfish, Pseudecheneis maurus, is described from the Song Thuy Loan drainage in Central Vietnam. Pseudecheneis maurus can be distinguished from congeners in having a combination of a very short adipose-fin base (1.2 times length of anal-fin base vs. 1.5-2.0 times; 15.7\% SL vs. 17.6-30.6), thoracic adhesive apparatus with sulcae not meeting at midline and the absence of distinct pale spots on the body.
\end{abstract}

Key words: Annam Cordillera, Southeast Asia, Glyptosterninae

\section{Introduction}

Sisorid catfishes of the genus Pseudecheneis Blyth, 1860, are diagnosed by a thoracic adhesive apparatus consisting of a series of transverse ridges (laminae) separated by grooves (sulcae) (de Pinna, 1996; Roberts, 1998), and are found in the upper reaches of rivers throughout the Subhimalayan and Indochinese region. Recent studies (Ng \& Edds, 2005; Ng, 2006a; Ng, 2006b) recognize eleven valid species of Pseudecheneis: P. sulcata (M'Clelland, 1842); P. paviei Vaillant, 1904; P. tchangi (Hora, 1937); P. immaculata Chu, 1982; P. sulcatoides Zhou \& Chu, 1992; P. sympelvica Roberts, 1998; P. crassicauda Ng \& Edds, 2005; P. serracula Ng \& Edds, 2005; P. eddsi Ng, 2006; P. stenura Ng, 2006; and P. suppaetula $\mathrm{Ng}, 2006$.

The ichthyofauna of the short coastal drainages that drain the eastern face of the Annam Cordillera in Central Vietnam has not been explored until recently, where it has been found to contain a considerable number of endemic species (e.g. Freyhof \& Serov, 2001; Ng \& Freyhof, 2005). During a recent ichthyological survey of one such drainage in Central Vietnam carried out by HHT, a specimen of Pseudecheneis was obtained from a region where the genus had not been previously reported. This specimen is here shown to belong to an undescribed species, which is described below as Pseudecheneis maurus, sp. nov.

\section{Material and methods}

Measurements were made point to point with dial calipers, and data recorded to tenths of a millimeter. Counts and measurements were made on the left side of specimens. Subunits of the head are presented as proportions of head length (HL). Head length and measurements of body parts are given as proportions of standard length (SL). Measurements follow those of $\mathrm{Ng} \&$ Rainboth (2001).

Material examined in this study is deposited in the following institutions: Academia Sinica, Institute of 
Zoology, Beijing (ASIZB), Natural History Museum, London (BMNH), California Academy of Sciences, San Francisco (CAS), Collection of Maurice Kottelat, Cornol [Switzerland] (CMK), Kunming Institute of Zoology, Kunming [China] (KIZ), University of Kansas Natural History Museum, Lawrence (KU), Muséum National d'Histoire Naturelle, Paris (MNHN), Naturhistoriska Riksmuseet, Stockholm (NRM), Department of Zoology Collection of Vertebrates, Oklahoma State University, Stillwater (OSUS), University of Michigan Museum of Zoology, Ann Arbor (UMMZ), Zoölogisch Museum Amsterdam (ZMA), and the Zoological Reference Collection, Raffles Museum of Biodiversity Research, Singapore (ZRC).

\section{Pseudecheneis maurus sp. nov.}

(Fig. 1)

Type material. Holotype: ZRC 50638, $54.8 \mathrm{~mm}$ SL; Vietnam: Da Nang province, Song Thuy Loan drainage, Ban $\mathrm{Na}$ hill station, Cat Lon stream, ca. $9 \mathrm{~km}$ along road before summit, 160'39.2"N 108 1'2.6"E, $722 \mathrm{~m}$ asl; H. H. Tan \& A. D. Tran, 28 February 2005.

Diagnosis. Pseudecheneis maurus is distinguished from all congeners in having a shorter adipose-fin base (1.2 times length of anal-fin base vs. 1.5-2.0 times; 15.7\% SL vs. 17.6-30.6), (except for P. sympelvica) thoracic adhesive apparatus with sulcae not meeting (vs. meeting) at midline and (except for $P$. immaculata) in lacking (vs. having) distinct pale spots on the body It further differs from $P$. immaculata in having a shorter pectoral fin (24.3\% SL vs. 32.0) and shorter and deeper caudal peduncle (length 21.2\% SL vs. 28.8; depth $6.0 \%$ SL vs. 4.0). from. It differs from $P$. paviei and $P$. sympelvica in having an elongate body with 38 vertebrae (vs. short body with 33-35 vertebrae) and from $P$. sympelvica in having separate (vs. fused) pelvic fins.

Description. Biometric data as in Table 1. Head and abdominal region narrow and strongly depressed. Dorsal profile rising gently from tip of snout to origin of dorsal fin, then almost horizontal or sloping very gently ventrally to end of caudal peduncle. Ventral profile horizontal to anal-fin base, then sloping very gently dorsally to end of caudal peduncle. Caudal peduncle long and moderately compressed. Anus and urogenital openings located at posteriormost extent of pelvic fin. Skin smooth, tuberculate in some areas. Lateral line complete and midlateral. Vertebrae $19+19=38$.

Head acutely rounded when viewed from above. Gill openings moderate, extending from posttemporal region to base of first pectoral-fin element. Head covered with thick, tuberculate skin. Ventral surface of head with unculiferous collar on distal margin of branchiostegal membrane immediately anterior to thoracic adhesive apparatus.

Thoracic adhesive apparatus consisting of 13 transverse ridges (laminae) separated by grooves (sulcae); sulcae not meeting at midline of adhesive apparatus. Adhesive apparatus extending from immediately posterior to collar on distal margin of branchiostegal membrane to immediately posterior to level of last pectoralfin ray.

Barbels flattened, and in four pairs. Maxillary barbel with ventral surface densely covered with papillae, and pointed tip; barbel extending about two-thirds of distance between its base and base of first pectoral-fin element. Distal half of barbel attached to snout via large, thin flap of skin. Nasal barbel with small flap of thin skin fringing posterior margin and extending midway to distance between posterior nares and anterior orbital margin. Inner mandibular-barbel densely covered with papillae; origin close to midline, extending to collar on distal margin of branchiostegal membrane. Outer mandibular barbel originating posterolateral of inner mandibular barbel, extending to level of anterior orbital margin. Eye small and almost rounded, subcutaneous and located on dorsal surface of head.

Mouth inferior, with moderately broad, thin papillate lips. Rictal lobe large and papillate. Premaxillary tooth band not exposed when mouth is closed. Premaxillary teeth short and conical, arranged in irregular rows on a moderately large quadrangular patch. Dentary teeth long, thin and somewhat rounded at tip; arranged in irregular rows on two separated, roughly triangular patches. 


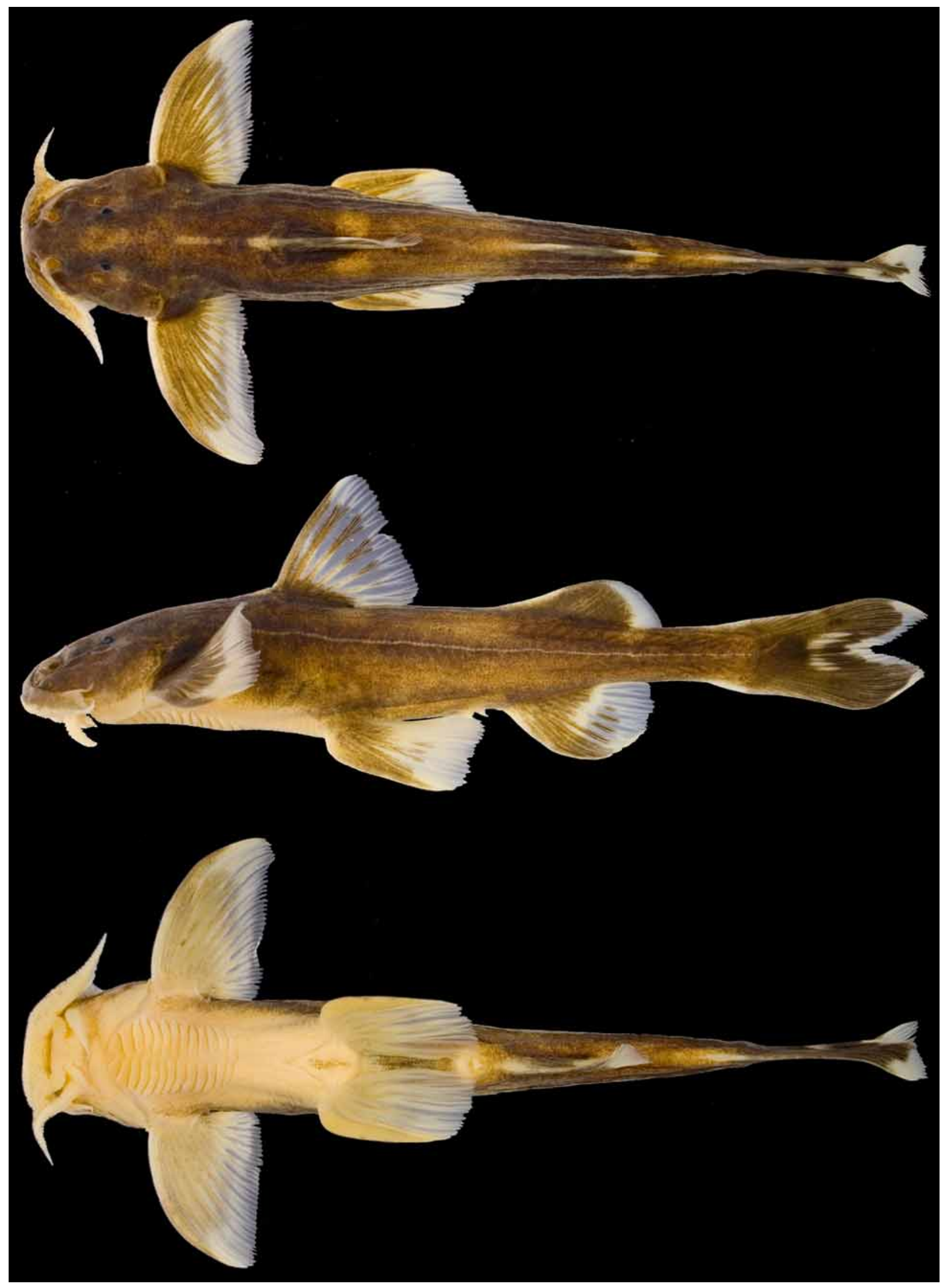

FIGURE 1. Pseudecheneis maurus, ZRC 50638, holotype, $54.8 \mathrm{~mm}$ SL; Vietnam: Cat Lon stream. Dorsal, lateral and ventral views. 
TABLE 1. Biometric data for holotype of Pseudecheneis maurus.

\begin{tabular}{|c|c|}
\hline \multicolumn{2}{|l|}{$\% \mathrm{SL}$} \\
\hline Predorsal length & 35.8 \\
\hline Preanal length & 64.8 \\
\hline Prepelvic length & 41.1 \\
\hline Prepectoral length & 17.9 \\
\hline Length of dorsal-fin base & 11.9 \\
\hline Anal-fin length & 13.9 \\
\hline Pelvic-fin length & 20.4 \\
\hline Pectoral-fin length & 24.3 \\
\hline Caudal-fin length & 23.9 \\
\hline Length of adipose-fin base & 15.7 \\
\hline Dorsal to adipose distance & 19.9 \\
\hline Post-adipose distance & 17.5 \\
\hline Caudal peduncle length & 21.2 \\
\hline Caudal peduncle depth & 6.0 \\
\hline Body depth at anus & 11.1 \\
\hline Head length & 22.4 \\
\hline Head width & 18.1 \\
\hline Head depth & 13.9 \\
\hline \multicolumn{2}{|l|}{$\% \mathbf{H L}$} \\
\hline Snout length & 59.3 \\
\hline Interorbital distance & 26.8 \\
\hline Eye diameter & 10.6 \\
\hline Nasal barbel length & 31.7 \\
\hline Maxillary barbel length & 61.8 \\
\hline Inner mandibular barbel length & 26.8 \\
\hline Outer mandibular barbel length & 48.8 \\
\hline
\end{tabular}

Dorsal-fin origin located at point through anterior third of body. First and second dorsal fin-ray elements not ossified, bearing i,6 rays, and fin margin straight. Adipose fin with very short base, 1.2 times anal-fin base length; located in middle third of postdorsal region. Adipose fin margin gently convex; posterior end deeply incised. Caudal fin forked, with i,7,8,i principal rays; procurrent rays symmetrical and extend only slightly anterior to fin base. Anal fin with short base extending less than half of adipose fin-base length and iii,7,i rays. Anal fin margin almost straight.

Pelvic-fin origin at vertical through second or third dorsal fin-ray base. Pelvic fin greatly enlarged, extending to base of first anal-fin ray. Anterior fin margin strongly convex, first element broadened and with regular striae on ventral surface; with i,5 rays. Pectoral fin greatly enlarged and with convex anterior margin, reaching to just beyond pelvic-fin base. First element not ossified, broadened and with regular striae on ventral surface; fin with i,11,i rays.

Coloration. In $70 \%$ ethanol: chestnut brown on dorsal and lateral surfaces of head and body, fading to 
light brown on ventral region. Dorsal surfaces of head and body with indistinct light brown patches on supraoccipital spine and immediately anterior to dorsal-spine base. Lateral surfaces of body with very faint light brown patches: one patch immediately posterior to last dorsal-fin ray and an elongate ovate spots on side of body immediately ventral to origin of adipose fin. Dorsal and anal fins with chestnut brown base and subdistal band. Adipose fin chestnut brown, with light brown anterior margin and margin along posterior twothirds of fin. Caudal fin chestnut brown, with small hyaline spot on lobes near horizontal midline and hyaline distal margin. Dorsal surfaces of pectoral and pelvic fin bases chestnut brown, with hyaline distal margin; ventral surfaces hyaline. Maxillary and nasal barbels chestnut brown dorsally and light brown ventrally.

Distribution. Presently known only from the Song Thuy Loan River drainage (of which the Cat Lon stream is a tributary) that drains the eastern face of the Annam Cordillera in central Vietnam (Fig. 2).

Habitat. The single specimen was obtained from a riffle zone of a small hill stream (ca 2-4 m wide, ca 10-30 cm deep). The bottom consists of fine gravel and granitic rocks, with exposed boulders along the banks and streamline (Fig. 3). The water was swift flowing and cool (ca $24{ }^{\circ} \mathrm{C}$ ). No other fish were obtained from this habitat, although at least six species of amphibian tadpoles were present (unpub. data).

Etymology. From the Greek mauros, meaning dark, in reference to the absence of distinct pale spots on the body of this species. Used as a noun in apposition.

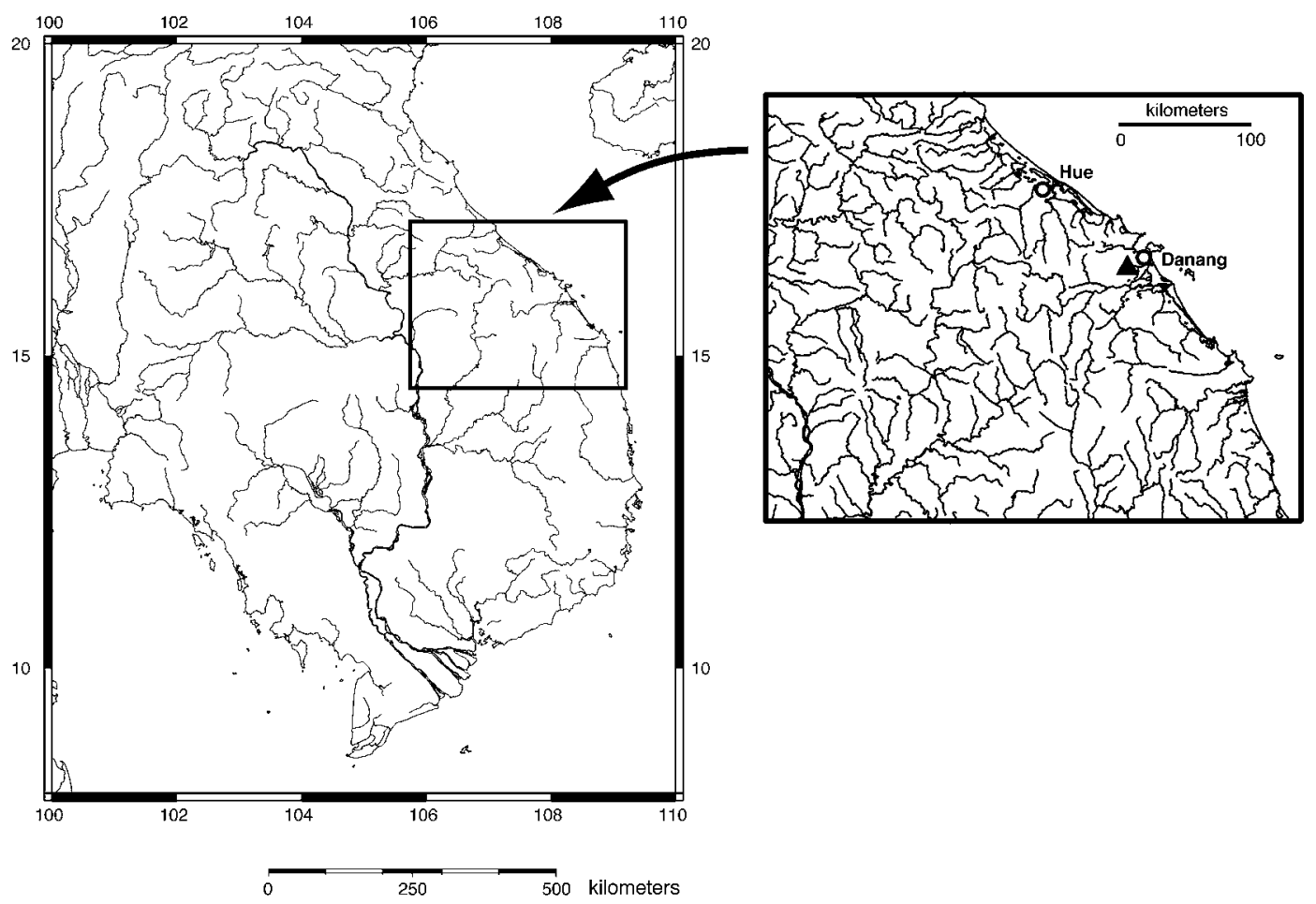

FIGURE 2. Map showing type locality of Pseudecheneis maurus (indicated by solid triangle).

\section{Discussion}

The relatively short adipose-fin base of $P$. maurus easily distinguishes the species from congeners. The thoracic adhesive apparatus of $P$. maurus is also distinctive, with the sulcae not meeting at the midline. Only $P$. sympelvica has an adhesive apparatus with a similar morphology, but it can be distinguished from $P$. maurus by the characters mentioned in the diagnosis. Pseudecheneis maurus represents the first record of the genus in river drainages draining the eastern face of the Annam Cordillera. The most geographically proximate species is P. sympelvica, which is found in the Nam Theun river drainage (part of the Mekong River drainage) that drains the western face of the Annam Cordillera (ca. $400 \mathrm{~km}$ to the northwest). However, in addition to the 


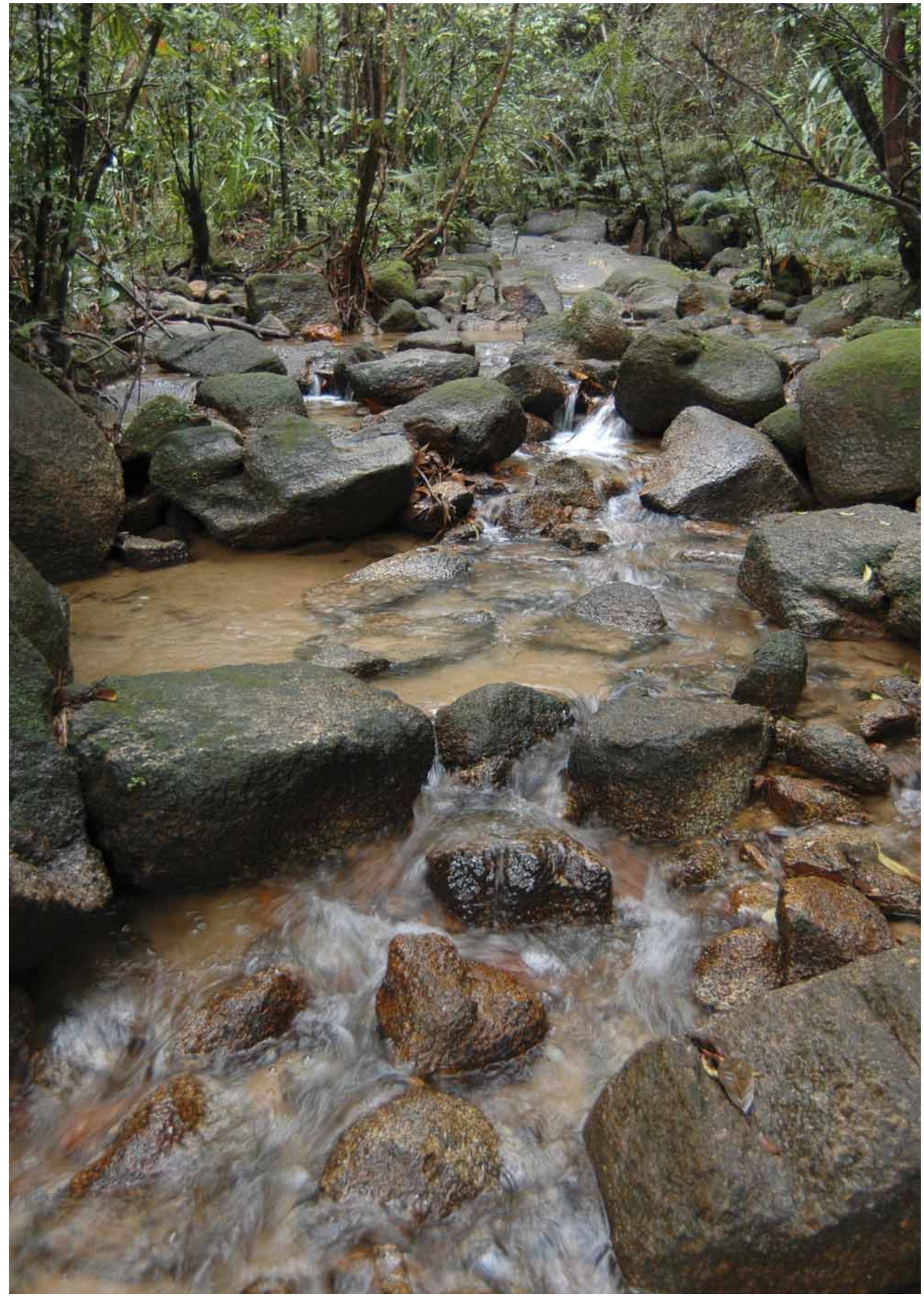

FIGURE 3. Photograph of Cat Lon stream, type locality of Pseudecheneis maurus. 
different vertebral counts, fused pelvic fins, different color pattern and longer adipose fin base of $P$. sympelvica as outlined in the diagnosis, $P$. sympelvica further differs from $P$. maurus in having a more slender caudal peduncle (depth $4.7-4.8 \%$ SL vs. 6.0).

The description of Pseudecheneis maurus from only a single specimen (only one specimen was obtained in spite of intensive sampling lasting about an hour on each of three separate occasions at the type locality) is justifiable in this case because of the clear differences in the morphology of this species from all its congeners. These differences are present in morphological characters (e.g. length of adipose-fin base, depth of caudal peduncle) that have been shown to be useful for diagnosing other congeners (Ng, 2006a; 2006b; Ng \& Edds, 2005). Furthermore, P. maurus is known from an area where the genus has not been previously recorded and where considerable endemicity in the freshwater ichthyofauna has been demonstrated (e.g. Freyhof \& Serov, 2000).

\section{Comparative material}

Pseudecheneis crassicauda: BMNH 1958.9.1.8 (holotype), 103.7 mm SL; BMNH 1958.9.1.9 (1 paratype),

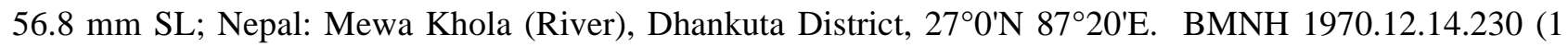
paratype), $136.8 \mathrm{~mm}$ SL; Nepal: Mewa Khola (River), Sanghu.

P. eddsi: KU 36872 (holotype), $84.1 \mathrm{~mm}$ SL; KU 29629 (5 paratypes), 40.5-74.4 mm SL; Nepal:

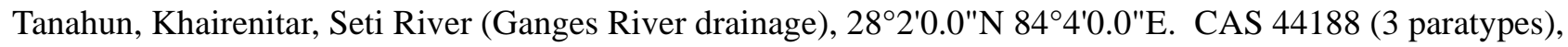
45.5-62.1 mm SL; CAS 50306 (30 paratypes), 34.7-45.8 mm SL; Nepal: Mahesh Khola, 24-32 km WNW of Kathmandu, on the road to Pokhara (Ganges River drainage). KU 29084 (3 paratypes), 55.8-94.4 mm SL;

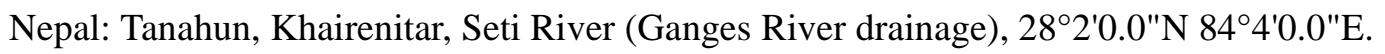

P. immaculata: BMNH 1987.9.17.5 (1 paratype), 80.9 mm SL; China: Yunnan, Deqin County, Liudongjiang. Additional data from Chu (1982).

P. paviei: BMNH 1987.9.17.24 (1 paratype of P. intermedius), $55.5 \mathrm{~mm} \mathrm{SL}$; China: Yunnan, Jingdong County, Dongbao. BMNH 2003.2.9.2-3 (2), 51.1-51.2 mm SL; China: Yunnan, Jingdong County, Yuanjiang drainage. MNHN 1935-0042 (1), 47.0 mm SL; Vietnam: Nghia Lo.

P. serracula: KU 29554 (holotype), 153.2 mm SL; Nepal: Mugu/Bajura, Jhugala, Karnali River, purchased at Jhugala, 29³1'18.0"N 8146'48.0"E. BMNH 1985.9.16.50-51 (2 paratypes), 48.0-48.2 mm SL; Nepal: Narayani River, Chitawan National Park. KU 28669 (5 paratypes), 41.5-56.5 mm SL; Nepal: Kanchanpur, Brahamadev, Mahakali River at Brahamadev, 294'54.1"N 808'30.1"E. KU 29038 (1 paratype), 58.0 mm SL; Nepal: Gulmi/Syangja, Kali Gandaki River at Ridi Bazar; 2756'6.0"N 8326'30.1"E. KU 35545 (2 paratypes), 48.0-95.3 mm SL; Nepal: Tanahun, Khairenitar, Seti River at Khairenitar, 28 2'0.0"N 84²'0.0"E. OSUS 15703 (4 paratypes), 31.6-59.3 mm SL; Nepal: Syangja, Kali Gandaki River at Nimaa. OSUS 15718 (9 paratypes), 34.1-75.5 mm SL; Nepal: Gulmi/Syangja, Kali Gandaki River at Ridi Bazar; 2756'6.0"N 83²6'30.1"E. OSUS 15729 (3 paratypes), 53.5-59.6 mm SL; Nepal: Baglung, Kali Gandaki River at Sumsaa Ghat (Binamaare). OSUS 15736 (6 paratypes), 19.8-54.4 mm SL; Nepal: Myagdi, Kali Gandaki River at Simaa. OSUS 16340 (1 paratype), $79.5 \mathrm{~mm}$ SL; Nepal: Chitawan, Narayani River at Narayanagarh, upstream from irrigation office. OSUS 16609 (1 paratype), $22.2 \mathrm{~mm}$ SL; Nepal: Chitawan, Narayani River at Amaltaari Ghat. OSUS 16637 (15 paratypes), 63.0-130.5 mm SL; Nepal: Chitawan, Narayani River at Narayangarh, upstream from irrigation office. OSUS 16695 (1 paratype), $62.3 \mathrm{~mm}$ SL; Nepal: Syangja, Kali Gandaki River at Nimaa. OSUS 17179 (1 paratype), 80.0 mm SL; Nepal: Syangja, Kali Gandaki River at Nimaa.

P. stenura: KIZ 199811999 (holotype), $132.1 \mathrm{~mm}$ SL; CAS 219177 (55 paratypes), 41.3-180.1 mm SL; China: Yunnan, Baoshan Prefecture, Longchuanjiang at Lianmengjie bridge (Irrawaddy River drainage).

P. sulcata: BMNH 1870.11.30.56 (3), 99.8-129.0 mm SL; BMNH 1889.2.1.2718-2719 (2), 60.9-89.8 mm SL; ZMA 121.861 (1), 87.8 mm SL; India: Meghalaya, Khasi Hills. BMNH 1928.9.17.5 (1), 83.8 mm SL; India: Meghalaya, Khasi Hills, Nong Priang stream. UMMZ 243677 (10) 46.6-118.1 mm SL; India: 


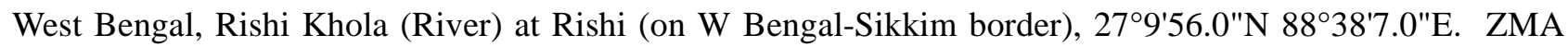
121.862 (1), $55.2 \mathrm{~mm}$ SL; India: Meghalaya, Nong Priang stream below Cherrapunji.

P. sulcatoides: CMK 5611 (3), 19.5-87.5 mm SL; China: Yunnan, Yangbi River from its confluence with Er-Hai River to about $20 \mathrm{~km}$ upstream of Yangbi. Additional data from Zhou \& Chu (1992).

P. suppaetula: NRM 36977 (holotype), $84.1 \mathrm{~mm}$ SL; NRM 36968 (1 paratype), $41.3 \mathrm{~mm}$ SL; NRM 36974 (2 paratypes), 66.6-77.5 mm SL; India: Himachal Pradesh, Ganges River drainage, upper reaches of Giri River, in Chhaila area (in the vicinity of Kotkhai), $31^{\circ} 6^{\prime} 15^{\prime \prime} \mathrm{N} 77^{\circ} 25^{\prime} 56^{\prime \prime} \mathrm{E}$.

P. sympelvica: ZRC 40359 (holotype), $55.0 \mathrm{~mm} \mathrm{SL}$; ZRC 40360 (1 paratype), $55.3 \mathrm{~mm}$ SL; Laos: Khammouan province, Nam Theun drainage, Nam Veo, tributary of Nam Phao, $25 \mathrm{~km}$ E of Lak Sao. CMK 12257 (3), 54.6-55.4 mm SL; Laos: Khammouan Province, Nam Theun, waterfall about $7 \mathrm{~km}$ downriver of NT2 dam site, $18^{\circ} 1^{\prime} 40^{\prime \prime N} 104^{\circ} 58^{\prime} 54^{\prime \prime E}$. CMK 15231 (1), 62.4 mm SL; Laos: Xiangkhouang Province, Nam Ngum, rapids downstream of Ban Latbouak, 19³6'20"N 103¹4'28"E. UMMZ 241107 (1), 43.7 mm SL; Laos: Luang Prabang Province, Nam Khan at Keng Noun (rapids), $10 \mathrm{~km}$ E of Luang Prabang.

P. tchangi: ASIZB 20010 (holotype), 120 mm SL; China: Yunnan (photographs examined).

\section{Acknowledgments}

We are grateful to the following for access to material under their care: Darrell Siebert (BMNH), David Catania (CAS), Maurice Kottelat (CMK), Andrew Bentley (KU), Patrice Pruvost (MNHN), Sven Kullander (NRM), Anthony Echelle (OSUS), Douglas Nelson (UMMZ), Isaäc Isbrücker (ZMA) and Kelvin Lim (ZRC), and to Zhang Chunguang (ASIZB) for providing photographs of the holotype of $P$. tchangi. HHT thanks Nguyen Xuan Quynh (Vietnam National University, Hanoi) and Tran Anh Duc, for logistic support and company during the field trip. This work was funded by support from the All Catfish Species Inventory (NSF DEB-0315963) to HHN and National University of Singapore research grant (R-154-000-222-112) to HHT.

\section{Literature cited}

Chu, X.-L. (1982) Phylogeny of the genus Pseudecheneis (Siluriformes: Sisoridae), with descriptions of two new species. Acta Zootaxonomica Sinica, 7, 428-437. [In Chinese, English summary]

de Pinna, M.C.C. (1996) A phylogenetic analysis of the Asian catfish families Sisoridae, Akysidae, and Amblycipitidae, with a hypothesis on the relationships of the neotropical Aspredinidae (Teleostei, Ostariophysi). Fieldiana: Zoology (New Series), 84, 1-83.

Freyhof, J. \& Serov, D.V. (2000) Review of the genus Sewellia with description of two new species from Vietnam (Cypriniformes: Balitoridae). Ichthyological Exploration of Freshwaters, 11, 217-240.

Freyhof, J. \& Serov, D.V. (2001) Nemacheiline loaches from Central Vietnam with descriptions of a new genus and 14 new species (Cypriniformes: Balitoridae). Ichthyological Exploration of Freshwaters, 12, 133-191.

Ng, H.H. (2006a) The identity of Pseudecheneis sulcata (M'Clelland, 1842), with descriptions of two new species of rheophilic catfish (Teleostei: Sisoridae) from Nepal and China. Zootaxa, 1254, 45-68.

Ng, H.H. (2006b) Pseudecheneis suppaetula, a new species of glyptosternine catfish (Teleostei: Sisoridae) from India. Zootaxa, 1267, 59-68.

Ng, H.H. \& Edds, D.R. (2005) Two new species of Pseudecheneis, rheophilic catfishes (Teleostei: Sisoridae) from Nepal. Zootaxa, 1047, 1-19.

Ng, H.H. \& Freyhof, J. (2005) A new species of Pseudomystus (Teleostei: Bagridae) from Central Vietnam. Copeia, 2005, 745-750.

Ng, H.H. \& Rainboth, W.J. (2001) A review of the sisorid catfish genus Oreoglanis (Siluriformes: Sisoridae) with descriptions of four new species. Occasional Papers of the Museum of Zoology the University of Michigan, 732, 134.

Roberts, T.R. (1998) Pseudecheneis sympelvicus, a new species of rheophilic sisorid catfish from Laos (Mekong basin). The Raffles Bulletin of Zoology, 46, 289-292. 